\title{
Principles of place names classifications
}

\author{
Aleksandra V. Urazmetova - Julia Kh. Shamsutdinova
}

\section{DOI: 10.18355/XL.2017.10.04.03}

\begin{abstract}
Toponyms (place names) represent language units denoting elements of topographic environment. The relevance of the study is caused by the need to develop the theory of toponymy and to systematize all the existing toponymic classifications. Place names have a complicated (multidimensional) nature, which should be taken into account while classifying them. This research is an attempt to highlight various principles according to which it is possible to group the place names. The research is based on 15000 British and 17000 American toponyms, received from toponymic dictionaries, reference books and electronic toponymic search systems GNIS (Geographic Names Information System) and Get-a-map. Toponyms can be classified according to the following principles: 1) parametric characteristics of an object, 2) ontological characteristics of an object, 3) type of toponymic basis, 4) etymological characteristics of place names, 5) motivational characteristics of place names, 6) chronological characteristics of place names, 7) structural characteristics of toponyms, 8) toponymic polysemy, 9) degree of toponymic nomination, 10) variety of toponymic nomination, 11) localization of an object. It is obvious that it is impossible to create a unified classification of place names, which would reflect the entire multidimensional nature of the toponymic vocabulary. Classifying toponymic nominations, one must consider the multifaceted (intra- and extra-linguistic) principles of allocation of toponymic units.
\end{abstract}

Key words: toponym, place name, toponymy, classification, principle, nickname

\section{Introduction}

Place names (toponyms) are the linguistic signs of a natural language denoting certain fragments of topographic space. These linguistic signs form a system, called $a$ toponymic system, which is artificially contractual in character. Toponyms are a kind of repositories of political, social and cultural views of the society, which display certain language trends and peculiarities of word formation. Toponyms make up a significant part of the lexical fund of the language. According to some researchers, "toponymic layer constitutes 2-3\% of common vocabulary" (Toporov, 1962: 56). There become fewer and fewer unnamed geographical objects as humankind learns and develops new geographical objects on the earth and expands its geographical horizons.

The geographical name is a part of the lexical system of a particular nation. It is formed according to "the fundamental laws of the language and it functions in speech in accordance with its basic rules and traditions" (Leonovich, 1994: 55). Any geographical object has both a geographic term, which determines its type, and a geographical name; therefore, a topographic object is "named twice", enriching the semantics of a toponym.

\section{Theoretical research base: condition of problem's study}

Methodological foundation of this work is based on the theoretical theses elaborated in the works of linguists in the sphere of onomastics (Boldyrev, 2012; Khvesko, 2007; Artemova \& Leonovich, 2010; Briggs; Gelling, Cole, 2003; Semple, 2013; Cameron, 1963; Mills 2003; Mawer, Stenton, 1925; Room, 1985; Nicolaisen, 1976; Reany, 1985 - in the sphere of British toponymy; Alderman, 2000; Beauchamp 2011; 
Gannett, 1902; Tomahin 1982 - in the sphere of American toponymy; Bach, 1953; Belyaev, 2014; Bily, 1996; Muryasov, 2013 - in the sphere of German toponymy; Rostaing, 1992; Nègre, 1990-1998; Deroy, Mulon, 1994; Beaurepaire, 1979; Pégorier, 1997 - in the sphere of French toponymy; Matveev, 2009; Bondaletov, 2012; Golev \& Dmitrieva, 2008; Sherbak, 2012 - in the sphere of Russian toponymy, etc.)

These linguists regarded toponymic units from different points of view taking into consideration various aspects of their many-sided structure (linguocultural, cognitive, ontological, functional, sociolinguistic, semantic, etymological, etc.). Some of them tried to classify toponyms according to a certain principle; however, an overall classification of toponyms has not been worked out yet.

\section{Materials and Methods}

The aim of this research is to provide and systematize different principles of place names classification, taking into account their complicated (multidimensional) nature. The research is based on 15000 British and 17000 American toponyms, received from toponymic dictionaries, reference books and electronic toponymic search systems GNIS (Geographic Names Information System) and Get-a-map. Methodology includes the methods of descriptive analysis, which consists in collecting and systematizing the collected facts, in their logical comprehension and identification of specific patterns. Taxonomic method as a variant of the descriptive method is used for the categorization of toponymic units into certain logical classes and subclasses. In some cases the method of quantitative analysis was used. It revealed quantitative relationships between different categories of place names; it also discovers the main mechanism of the development of toponymic systems of different territorial variants of the English language.

\section{Results and Discussion}

The main disadvantage of classification schemes of toponyms is the impossibility to "fit all the variety of geographical names into the Procrustean bed of one classification" (Murzaev, 1996: 115). However, some linguists tried to classify toponyms combining different principles simultaneously. One of the first researchers to classify place names in any systematic manner was George R. Stewart. In 1954, he published an article in Names entitled "A classification of place names". His typology based on the "naming-process" recognizes ten main toponym types: 1) descriptive names and compass-point names (names that describe and characterize the object's quality or its location; 2) associative names (names that evoke associations with different objects); 3 ) incident names (names from an event associated with a person, G. Stewart also refers to this group acts of God, calendar names, animal names, names of human actions, names from feelings, names from sayings); 4) possessive names (names originated from some idea of ownership); 5) commemorative names (names given in memory or in honor of outstanding people and names for abstract virtues); 6) commendatory names (names given by some attractive peculiarities of a geographical object); 7) folk etymologies (names with false etymology); 8) manufactured names (names which have been consciously constructed of fragments of other words, or names from initials, by reversals of letters or syllables, or in other ways); 9) mistake names (names appeared from a mistake made in the transmission from one language to another, either from inaccurate hearing of what was said, or because of faulty rendering of the sounds in writing); 10) shift names (names which have been moved from one location to another) (Stewart, 1970: xxix).

XLinguae, Volume 10, Issue 4, October 2017, ISSN 1337-8384, eISSN 2453-711X 
A mixture of lexical, grammatical and semantic principles is considered as the disadvantage rather than the advantage of such classifications. The scientific approach assumes that the set is divided into subsets as many times as many principles of division there are, meanwhile the divided subset can also be subdivided.

It is obvious that it is impossible to create a unified classification of place names, which would reflect the entire multidimensional nature of the toponymic vocabulary. Classifying toponymic nominations, one must consider the multifaceted (intra- and extra-linguistic) principles of allocation of toponymic units, such as: 1) parametric characteristics of an object, 2) ontological characteristics of an object, 3) type of toponymic basis, 4) etymological characteristics of place names, 5) motivational characteristics of place names, 6) chronological characteristics of place names, 7) structural characteristics of toponyms, 8) toponymic polysemy, 9) degree of toponymic nomination, 10) variety of toponymic nomination, 11) localization of an object.

1. Classification based on parametric characteristics of an object involves the division of place names into macrotoponyms (names of large geographical objects and political-administrative units) and microtoponyms (individualized names of small geographical objects, reflecting the peculiarities of the local landscape, familiar only to local residents). There exist no rigid boundaries between these types; however, it can be confirmed that macrotoponyms are functionally more stable and standardized, while microtoponyms are characterized by relative instability and mobility.

Depending on geopolitical, economic and socio-cultural significance of geographical objects denoted by the place names one can differentiate between hypertoponyms (names of the continents, oceans, countries), macrotoponyms (major regions, states, capitals, mountain ranges, major seas, rivers, islands), regionyms (names of cities, areas, rivers, mountains of regional significance) and microtoponyms (names of small objects in some localities known only to a limited circle of people, e.g. ravines, fields, forests, buildings, roads, parks, quarters) (Muryasov, 2015: 73).

2. Classification based on ontological characteristics of an object is characterized by worldwide orderliness and uniformity. The peculiarity of this classification is that "toponymic categorization duplicates the structure and the content of the categories of natural objects, i.e. it forms ontological model of the categorization of the world" (Sherbak, 2012: 90). Despite the fact that toponymic lexis presents an extensive layer in the language system, the diversity of place names can be reduced to a relatively small number of types. They can be divided into two groups: 1) names of natural objects and 2) names of manmade objects.

Names of natural objects include hydronyms, oronyms, drymonyms and insulonyms. Hydronyms are the names of all water objects; the branch of linguistics that studies hydronyms is called hydronymy. The hydrographic network, representing a set of inland water bodies and streams, includes oceans, seas, rivers, lakes, swamps and reservoirs. Names of oceans (the smallest toponymic class) are combined by the term oceanonyms, names of the seas belong to pelagonyms, names of rivers - to potamonyms, names of lakes - to limnonyms, names of swamps - to gelonyms. Names of small hydrographic objects (with a narrow field of use, e.g. brooks, springs, wells) commonly refer to microhydronyms. Oronyms combine the names of relief elements (mountains, headlands, hills, hillocks, hollows); the section of toponymy that studies oronyms is called oronymy. Speleonyms (names of caves, chasms, grottoes, mines and entire underground systems) also belong to oronyms. Drymonyms are the names of forests; subsection of toponymy studying drymonyms is called drymonymy. Insulonyms is a subclass of place names, combining the names of islands. Some names can belong to different groups simultaneously, for example, the underground rivers and lakes, belong to hydronyms (potamonyms) and oronyms (speleonyms).

Names of manmade objects include horonyms, oykonyms, urbanonyms. Horonyms are the names of territories that have definite boundaries (countries, 
administrative, historical, geographical and economic regions); the sphere of linguistics dealing with the study of horonyms is called horonymy. Oykonyms (names of settlements) are divided into astionyms (names of urban settlements) and comonyms (names of rural settlements); the part of toponymy, dealing with oykonyms is called oykonymy. Names of local objects (blocks, streets, squares, boulevards, alleys, promenades, avenues, memorial monuments, theatres, museums, cinemas, cafes, hotels, shops, private houses and other small sites within settlements) are united under the term urbanonyms; the sphere, dealing with urbanonyms is called urbanonymy.

There is a number of terms that describe the elements of a local urbanonymic system: hodonyms (street names), agoronyms (square names), microhoronyms (names of intercity areas, neighborhoods), ergonyms (names of enterprises), oikodomonyms (names of buildings), ecclesionyms (names of temples, churches, monasteries, chapels), dromonyms (road names), nekronyms (names of cemeteries), microdrimonyms (names of forests and parks). Urbanonyms usually refer to microtoponyms as they are known only to a limited number of people living in a particular area.

3. According to the classification of toponyms depending on the type of their basis, which relates to a certain lexico-semantic or thematic group, one can differentiate anthropotoponyms, topotoponyms, ethnotoponyms, zootoponyms, phytotoponyms, ergotoponyms etc. Anthropotoponyms are geographical names derived from anthroponyms (names of human beings, e.g. Columbus, Baltimore, Washington, Fort Johnson, Woodrow Wilson Bridge, Cape Kennedy); topotoponyms - geographical names derived from existing toponyms or geographical terms (river Mississippi $\rightarrow$ state Mississippi, river Missouri $\rightarrow$ state Missouri); ethnotoponyms are geographical names derived from tribal names, names of nations and other ethnic units (Kansas, Massachusetts, Dakota, Utah, Essex, Cornwall, Devon, Dorset, Hitchin, Oundle, Threekingham, Normanton, Irby); zootoponyms are geographical names derived from zoonyms (names of animal species, e.g. Bearpaw Creek, Beaver, Buffalo, Squirrel, Butterfly, Eagle, Fox, Lizard); phytotoponyms are toponyms derived from phytonyms (names reflecting flora, e.g. Big Oak Mountain, Birch Creek, Willowwood Park, Alder Lake); ergotoponyms are geographical names reflecting social status and professional activity of a person (Artist Point, Butcherknife Canyon, Driver, Hunter Creek, Lawyers Hill, Patroon Creek, Weaver), etc.

4. Depending on their origin, toponyms are subdivided into native, borrowed and hybrid ones. Native place names prevail among the toponyms of Great Britain (54\%) and the USA (52\%). British and American native toponyms are the names of Anglo-Saxon origin (Suffolk, Liverpool, Oxford). Borrowed names adapt to the phonetic and grammatical peculiarities of the borrowing language. Borrowed British toponyms can be of Celtic (Avon, Dover, Glasgow), Latin (Pontefract, Mellifont, Balne), Scandinavian (Lowestoft, Kirby, Braithwaite) and Norman-French (Beaulieu, Belmont, Belvoir) origin. Borrowed place names of the USA are presented by a larger number of language sources because of the peculiarities of the historical development of the country. Depending on the language source, borrowed place names of the USA are classified into the following groups: nominations of Indian (Arizona, Massachusetts, Mississippi), Spanish (Rio Grande, El Paso, San Francisco), French (Louisville, Belmont, Du Bois), Dutch (Amsterdam, Van Buren, Bronx), German (Harrisburg, Baden, Enhaut), Finnish (Ojala, Onni, Sampo), Greek (Sparta, Calypso, Achilles), Russian (Aleksandrovsk, Nikolaief, Baranof), Italian (Mantua), Latin (Marcellus), Swedish (Malung), Norwegian (Oslo), Danish (Odense), Polish (Panna Maria), Japanese (Mikado), Czech (Praha) and Arabic (Abdal) origin. Hybrid place names present a combination of native and borrowed elements $($ Cornwall $=$ Celtic tribal name (meaning 'peninsula people') + Old English walh (meaning 'Briton').

XLinguae, Volume 10, Issue 4, October 2017, ISSN 1337-8384, eISSN 2453-711X 
5. Classification based on motivational characteristics of place names or the clarity of their inner form presupposes two groups of geographical names: motivated toponyms with clear inner form (Bearpaw Mountain, Newtown, Oakland, Oceanside) and non-motivated toponyms with vague obscure semantics, the meaning of which is impossible to decipher (Arran, Nefyn, Rathlin, Rosyth, Scramoge, Wenvoe). Over time, place names can move from one group to another.

6. The basis for the chronological classification of place names is the division between the archaic (ancient, obsolete, disused) toponyms (New Amsterdam) and contemporary (current) place names (New York).

7. Classification based on the structural principle differentiates simple (Dawn, Deer, Park, Herman, Happy), derivative (Birmingham, Buckingham, California, Gatwick, Middleton), compound (Bridgewater, Lakewood, Longview, Oceanside, Springfield) and complex (Blue Mountains, Death Valley, Elmwood Place, Michigan City, Mount Forest, State of Colorado) place names.

8. According to the principle of toponymic polysemy (number of objects denoted by a toponym) place names are subdivided into one-object, multi-object and empty ones. Toponyms denoting one geographical object (or ideal toponyms) perform the individualizing function to the utmost (town Dinosaur in Colorado, town Viper in Kentucky). Multi-object toponyms denote several geographical objects (Kentucky name of settlements in the States of Mississippi, Illinois, Arkansas; settlements with the name Arizona are found in the States of Texas, Nevada, Louisiana; the city of Petersburg is found 35 times on the map of the USA; the name Big Lake, which can refer to lakes, reservoirs, swamps and settlements, is observed 183 times; toponym Little Creek belongs to 506 different geographical objects (GNIS). Toponymic polysemy is a characteristic feature of the US toponymy. Empty toponyms do not refer to any existing geographical objects, i.e. they are the names of fictional nonexistent geographical objects (on the high-road to Needham, in Queer Street).

9. According to the degree of toponymic nomination place names are divided into primary (nominations derived from common names, e.g. Hunter Place, Red Mouth Creek, Riverwood, Tornado Canyon) and non-primary (nominations derived from proper names, e.g. Columbus, Hercules, Hudson River, Saint Terese, Washington) (Superanskaya, 1967: 38-41).

10. Depending on the variety of toponymic nomination, we differentiate between primary and secondary toponyms. The primary toponymic nomination presents an actual toponym, while the secondary nomination (giving a new name for an already named object) is the toponymic nickname, acting as an alternative name, which should be considered as a variant of an actual place name, for example Florida is the primary nomination of the state; at the same time this geographical object has a number of secondary nominations (nicknames): Sunshine State, Everglade State, Alligator State, Citrus State, Orange State, Peninsula State, Flower State, Gulf State, God's Waiting Room, Hurricane State, La Florida, Manatee State, Tropical State (Urazmetova, 2014: 181).

11. Cultural opposition "ours - theirs" is realized in the classification of toponyms according to the principle of localization of an object. The term "our" toponyms implies geographical names, denoting objects within the examined language area ("our" names of Great Britain and the USA are Washington, Alabama, New York, Mississippi, Birmingham, Thames, London, etc.). "Their" toponyms represent geographical names, denoting objects outside the language area in question (Norway, Argentina, Qatar, Sierra Leone, The Netherlands, Thailand, Spain). We can also include here the group of "semi-our" or "semi-their" toponyms, denoting place names of the same language, but of different countries and cultures, such as place names in New Zealand and Australia.

\section{Conclusion}


There are a great number of place names in the English language. We analyzed over 32000 place names of Great Britain and the USA and distinguished 11 main principles according to which toponyms can be classified. The specificity of geographical names lies in the fact that along with naming and identifying objects they reflect, capture and retain social and historical facts in the development of the society, bringing ideological messages from the past to our daily lives. Toponyms are regarded as a result of human cognitive activity, establishing relations between different entities in the world and expressing this relationship in the created name. Onomastic units represent the world the way we live in, the way it is seen, learnt, comprehended and reflected.

\section{Bibliographic references}

ALDERMAN, D. 2000. A street fit for a King: naming places and commemoration in the American South. Professional Geographer. http://web.utk.edu/ dalderma/mlkstreet/aldermanpg2000b.pdf.

ARTEMOVA, A. F. - LEONOVICH O. A. 2010. Geograficheskie nazvanija Velikobritanii. Inostrannye jazyki v shkole. Moskva, (1), pp. 60-67. ISSN: 0130-6073. BEAUCHAMP, W. M. 2011. Aboriginal Place Names of New York. Albany: New York State Education Department. ISBN: 978-5-8747-8300-6.

BEAUREPAIRE, F. 1979. Les Noms des communes et anciennes paroisses de la Seine-Maritime. Paris. ISBN: 2-7084-0040-1.

BELYAEV, A. N. 2014. O rekursivnom metode v issledovanii substratnoi toponimii vostochnoi Germanii. Tambov: Gramota, (3), pp. 34-37. ISSN: 1997-2911.

BILY, I. 1996. Ortsnamenbuch des Mittelelbegebietes. Berlin: Akademie Verlag. ISBN 3-05-002505-0; ISBN 978-3-05-002505-6.

BOLDYREV, N. N. - CHISTYAKOVA E. V. 2012. Evaluative potential of landscape lexis of modern English language. Vestnik Tambovskogo universiteta. Tambov, 7 (111), pp. 22-27. ISSN: 1810-0201.

BONDALETOV, V. D. 2012. Russkaja onomastika. Moskva. ISBN: 978-5-39703151-6.

BRIGGS, K. Maps of English place-name element distribution. http://keithbriggs.info/English_placename_element_distribution.html.

CAMERON, K. 1963. English PlaceNames. London: B.T. Batsford. ISBN: 0713473789, ISBN13: 9780713473780.

DEROY, L. - MULON, M. 1994. Dictionnaire des noms de lieux Paris. ISBN: 9782-85036-195-1.

GANNETT, H. 1902. Origin of Certain Place Names in the United States. Washington: Government printing office. ISBN: 9781358765247.

GELLING, M. - COLE, A. 2003. The Landscape of Place-Names. Stamford. ISBN: 1-900289-26-1.

GEOGRAPHIC NAMES INFORMATION SYSTEM.

http://geonames.usgs.gov/apex/f?p=136:1:12972120087300.

GOLEV, N. D. - DMITRIEVA, L. M. 2008. Edinstvo ontologicheskogo i mental'nogo bytija toponimicheskoj sistemy (k problematike kognitivnoj toponimiki).

Voprosy onomastiki, (5), pp. 5-18. ISSN: 1994-2400, eISSN: 1994-2451.

KHVESKO, T. V. 2007. Stranovedenie: tetimologija toponimov Velikobritanii: uchebnoe posobie / T.V. Khvesko. Tjumen'. ISBN: 978-5-98100-115-4.

LEONOVICH, O. A. 1994. Ocherki anglojazychnoj onomastiki. Moskva: Interpraks. ISBN: 5-85235-161-X.

MATVEEV, A. K. 2009. Tendencies and practices in the contemporary Russian urbonomination. Voprosy onomastiki, (7), pp. 100-105. ISSN: 1994-2400. eISSN: 1994-2451.

XLinguae, Volume 10, Issue 4, October 2017, ISSN 1337-8384, eISSN 2453-711X 
MAWER, A. - STENTON, F. M. 1925. The place-names of Buckinghamshire. Cambridge: The University Press. ISBN: 0904889491.

MILLS, A. D. 2003. Oxford Dictionary of British Place-Names. Oxford. eISBN: 9780191739446.

MURZAEV, E. M. 1996. Geography in the names. Moscow. ISBN 5-02-016806-8.

MURYASOV, R. Z. 2013. Toponimy v sisteme jazyka. Vestnik Bashkirskogo universiteta, (3), pp. 753-762. ISSN: 1998-4812.

MURYASOV, R. Z. 2015. Imena sobstvennye v sisteme jazyka. Ufa: RIC BashGU. ISBN: 978-5-7477-3947-5.

NEGRE, E. 1990-1998. Toponymie générale de la France. Genève. ISBN: 978-2-60000133-5.

NICOLAISEN, W. F. H. 1976. Scottish Place-names. Edinburgh: John Donald Publishers Ltd. ISBN: 0-7134-3253-5.

PEGORIER, A. 1997. Les Noms de lieux en France: glossaire de termes dialectaux. Paris: Institut geographique national. ISBN: 978-2-85595-048-8.

REANY, P. H. 1985. The Origin of English Placenames. London: Routledge and Kegan Paul. ISBN-10: 071020728X, ISBN-13: 978-0710207289.

ROOM, A. A. 1985. Concise Dictionary of Modern Place Names in Great Britain and Ireland. Oxford; New York: Oxford University Press. ISBN-10: 0192819003, ISBN13: 978-0192819000.

ROSTAING, CH. 1992. Les Noms de lieux, 11e édition. ISBN 978-2-13-044015-4.

SEMPLE, S. J. 2013. Perceptions of the Prehistoric in Anglo-Saxon England: Religion, Ritual and Rulership in the Landscape. Oxford: Oxford University Press. ISSN/ISBN: 9780199683109.

SHERBAK, A. S. 2012. Kognitivnye osnovy regional'noj onomastiki. Tambov: Izdatel'skij dom TGU im. G.R. Derzhavina. ISBN: 978-5-89016-789-7.

STEWART, G. R. 1970. A Concise and Selective Dictionary for the Continental United States of America. New York, Oxford: Oxford University Press. ISBN: 0195001214, ISBN13: 9780195001211.

SUPERANSKAYA, A. V. 1967. Svjaz' toponimov s nazyvaemymi ob'ektami. Istorija toponimiki v SSSR. Moskva: AN SSSR.

TOMAHIN, G. D. 1982. Amerika cherez amerikanizmy. http://www.twirpx.com/file/234428/.

TOPOROV, V. N. 1962. Iz oblasti teoreticheskoj toponomastiki. Voprosy jazykoznanija, (6), pp. 3-13. ISSN: 0373-658X.

URAZMETOVA, A. V. 2014. Secondary nomination in place-name study. ISBN: 978-5-7477-3644-3. 
Words: 3380

Characters: 24520 (16,6 standard pages)

Associate Prof. Aleksandra Vladimirovna Urazmetova, PhD.

Department of Romance and Germanic Philology

Bashkir State University

Kommunisticheskaya 19

$450076 \mathrm{Ufa}$

Russia

urazmetova82@mail.ru

Assistant Prof. Julia Khanifovna Shamsutdinova

Department of Romance and Germanic Philology

Bashkir State University

Kommunisticheskaya 19

450076 Ufa

Russia

s.july.honey@gmail.com 